\section{Abstractions}

\section{BOOK REVIEW AUTHOR}

When Yadin Dudai reviews books, he begins by having an imaginary conversation with the book's author. But things get complicated when he knows the writer professionally. When Dudai reviewed the autobiography of eminent neuroscientist Eric Kandel (see page 157), he had the added difficulty of evaluating someone he knows and respects highly. Nature caught up with Dudai to discuss how he resolved his reviewing difficulties.

How daunting was it to review a book by a Nobel laureate and leader in your field? The only authorities in science are the data, and this should, in theory, solve any potential problem of authority-phobia - even for the most timid postdoc. In practice, I try to dissociate the person and the book, and review the writing, not the author. Of course, this is impossible for an autobiography.

\begin{abstract}
How has reviewing the tale of Kandel's career made you reflect on your own? It has intensified my appreciation of the revolution that has occurred in neuroscience in the past 30 years, which Kandel both predicted and led. It also calls into focus the pros and cons of reductionism. Reviewing this book, In Search of Memory, made me revisit the conceptual framework that says that to understand the brain you need to look at it more or less one cell at a time. In my review, I applauded the stunning success and potential of the reductionist approach, but I also wanted to remark that it is not the sole player in the field of brain research, and is not omnipotent.
\end{abstract}

\section{What have you learned from writing} reviews in general?

Respect for alternative world views and scientific styles. For example, I wrote a review a while back on a book about another prominent scientist, Seymour Benzer, the pioneer of modern neurogenetics. It became clearer to me, even though I know him well, how different from mine his style of doing science was. Such books epitomize that there are multiple successful ways to do things.

\section{What are you reading now and why?} I watch movies - good films are literature with extra sensory dimensions. I am interested in cognitive evolution as reflected in cinema, which is a very young cultural organ. I just watched three movies that deal with sudden disappearance: one by the British-born director Alfred Hitchcock, The Lady Vanishes; one by the Italian director, Michelangelo Antonioni, L'Avventura; the third by the French-born director George Sluizer, The Vanishing. They deal with the same elementary human anxiety, yet their approach, style and emotive effects are so different. The human mind can follow so many routes to a goal... just as in science.

\section{MAKING THE PAPER}

\section{Alan Aderem}

\section{A Seattle institute tackles the workings of the immune system.}

Ever since Seattle's Institute for Systems Biology was founded in 2000, co-director Alan Aderem and his colleagues have been gearing up for the type of experiment published on page 173 of this issue. They are working to elucidate the complex networks that regulate the body's immune system. And they use both computational and experimental approaches, with each of the techniques informing and validating the others.

Aderem is particularly interested in finding out how the immune response is regulated by macrophages - a group of white blood cells that fight foreign particles such as bacteria. These cells produce a slew of substances, called cytokines, which target invaders and call other immune cells into action. Once the danger passes, the macrophages help to call off the immune response that, left unchecked, can damage the body's own tissues. But how do macrophages orchestrate this regulation?

To get to the answer, Aderem and his colleagues opted for a 'systems biology' approach. Starting with a clean slate, they investigated the entire cell machinery rather than just focusing on specific aspects of it. The overall strategy was developed during discussions with other faculty members. "We would ask: how can we approach this kind of problem? What tools to we need?" says Aderem.

The first step was to use microarray chips to identify various sets of genes turned on at different times after mouse macrophages were exposed to a bacterial toxin. The team suspected that any transcription factors in the first set of genes would turn on genes in the second set, and transcription factors in that set would turn on genes in the third, and so forth.

Armed with this assumption, they used two computational tools, called MotifMogul and Cytoscape, to identify the transcription factors

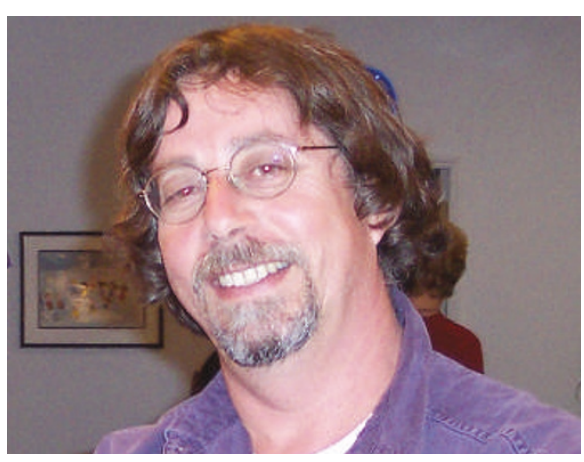

within the first set of expressed genes that worked in concert to turn on specific genes in the second set. In this way, they began to build molecular networks, showing how different molecules interact to turn the immune response on and off.

To test whether their strategy was working, they focused on specific molecules within the networks and tested their functions in the immune system using a range of experimental techniques, including knockout mice. Biologists are sometimes sceptical of computational approaches. But the key, says Aderem, is that "computational data are validated by experiments". And experiments, in turn, improve computational tools. "MotifMogul is a program that learns, so it will work better next time," he says.

Scientists at the Seattle institute developed the necessary computational and experimental tools over the past six months and validated them using simpler organisms such as yeast. The assumption they were banking on was that transcription activates subsequent waves of transcription factors. But in some situations, protein phosphorylation or other mechanisms regulate transcription. For such systems, other tools would be needed to build networks."In this case our strategy worked," says Aderem, "it hasn't in others."

"Our paper shows our approach is extremely powerful," adds Aderem. "If we understand clearly how immune responses unfold, we can perturb them selectively." And that could eventually lead to cures for autoimmune diseases and more effective vaccines.

\title{
QUANTIFIED AUSTRALIA
}

\section{A numerical perspective on Nature authors.}

lan Hutton has spent the past 25 years researching and recording the fauna and flora of Lord Howe Island, Australia. His roles range from curator for the local museum and organizer of weeding ecotours to surveyor of seabirds.

Hutton often teams up with visiting scientists to study individual plant or animal species on the island. Lord Howe may be isolated, but Hutton says that the Internet and e-mail have made research, communications and collaboration with scientists overseas much easier. He has a long-standing association with researchers from the Royal Botanic Gardens at Kew in Britain - their most recent collaboration provides evidence for sympatric speciation (divergence without geographical isolation) in two species of palm endemic to Lord Howe (see page 210).
101 manuscripts have been submitted to Nature from Australia this year $(<3 \%$ of all manuscripts).

46 authors in Australia have contributed to original research published in Nature this year ( $<2 \%$ of published authors).

4,183 downloads have been made of Hutton and colleagues' paper on speciation in palms since its advance online publication on 8 February 2006.

13,000 hours have been spent weeding as part of Hutton's ecotours. 